\title{
Effect of Different Storage Conditions on Nutritional and Quality Parameters of 'Sweetheart' Cherry
}

\author{
V. Palma, A.C. Agulheiro-Santos, \\ G. Machado, A.E. Rato and M.J. Cabrita \\ Universidade de Évora \\ Instituto de Ciências Agrárias e \\ Ambientais Mediterrânicas (ICAAM) \\ Escola de Ciências e Tecnologia \\ 7000 Évora \\ Portugal
}

\author{
M. Lozano and D. Gónzález \\ Instituto Tecnológico Agroalimentario \\ (INTAEX) \\ Ctra. San Vicente s/n \\ Finca Santa Engracia 06071 \\ Badajoz \\ Spain
}

Keywords: sweet cherry, cold storage, modified atmosphere, controlled atmosphere, total anthocyanins, total phenolics, total antioxidant activity

\begin{abstract}
The sweet cherry 'Sweetheart', although having a short shelf life, is highly appreciated by consumers due to its organoleptic characteristics. Different storage methods were tested to study the maintenance of quality during a period of 27 days: 1) cold (air at $1{ }^{\circ} \mathrm{C}$ and $95 \%$ relative humidity) (CC), 2) cold and polypropylene film bags $\left(1^{\circ} \mathrm{C}\right.$ and $95 \%$ relative humidity) (MA) and 3$)$ cold and controlled atmosphere $\left(1^{\circ} \mathrm{C}\right.$, 95\% $\mathrm{RH}, 10 \% \mathrm{CO}_{2}$ and $8 \% \mathrm{O}_{2}$ ) (CA). Quality parameters tested included external colour $\left(L^{*}, a^{*}, b^{*}\right)$, total soluble solids (TSS), and titratable acidity (TA). To evaluate nutritional quality anthocyanins, total antioxidant activity, and total phenolics were measured. Results allow us to say that phenolic compounds were relatively stable and similar during storage in $\mathrm{CC}$ and MA. Cherries stored under $\mathrm{CA}$ conditions presented lowest concentrations of phenolic compounds. Phenolic compounds, total anthocyanins and antioxidant activity were inversely correlated with values of colour coordinates. Considering all the evaluations done during this work it is unquestionable that fruits stored in controlled atmosphere conditions had significantly different quality.
\end{abstract}

\section{INTRODUCTION}

Sweet cherries are non-climacteric fruits, highly perishable but an interesting commodity for small farmers of S. Julião region and a profitable product for the Portuguese market. Harvest season is very short and the use of cold storage is recommended to delay deterioration and extend shelf life. Cold storage seems to be an appropriate storage method giving good results (Bernalte et al., 2003; Sampaio et al., 2006). Alternatively, the use of plastic bags promoting a passive MAP modified atmosphere packaging, or controlled atmosphere can improve shelf life (Meheriuk et al., 1995; Esti et al., 2002; Petracek, 2002; Bernalte et al., 2003; Conte et al., 2009). Sweet cherry cold storage has been studied for a long time by different researchers and it can be concluded that temperatures of $0-2^{\circ} \mathrm{C}$ and $90-95 \%$ of $\mathrm{RH}$ allow a larger shelf life (Looney et al., 1996; Crisosto et al., 1993; Agulheiro-Santos et al., 2009). Also different modified atmospheres were tested obtaining longer shelf life but distinct changes in quality parameters (Andre et al., 1982; Navarro et al., 1993; Meheriuk et al., 1995). The use of controlled atmosphere storage was tested by Porritt and Mason (1965) and they noticed a better appearance in CA stored cherries compared with air-stored fruit. Chen et al. (1981) tested low oxygen storage and obtained good results for appearance, green stem colour and fruit acidity. Patterson (1982) tried controlled atmospheres, with high $\mathrm{CO}_{2}$, and observed good brightness and acidity of fruits, but degradation of green stem colour. Sweet cherry firmness was observed by Chapon and Bony (1990) and also colour improved by storage in $0.5-2 \% \mathrm{O}_{2}$ (Chen et al., 1981) or $20-25 \% \mathrm{CO}_{2}$ (Patterson, 1982). 'Sweetheart' cherries stored at $1{ }^{\circ} \mathrm{C}, 95 \% \mathrm{RH}, 10 \% \mathrm{CO}_{2}$ and $8 \% \mathrm{O}_{2}$ exhibited better tissue turgidity, higher $\mathrm{L}^{*}$ values and better visual aspect of their stems than fruits stored under 
cold conditions with or without plastic bags; nevertheless SSC and acidity were also lower for these fruits (Agulheiro-Santos et al., 2009). According to Vursavus et al. (2006) firmness is another important attribute of sweet cherries and is often used for quality assessment. Skin colour is the most important indicator of quality and maturity of fresh cherries and depends on the anthocyanin content (Esti et al., 2002). Losses in nutritional quality are not well known during storage (Vursavus et al., 2006; Gonçalves et al., 2007). In spite of intensive research, the effect of storage on nutritional quality of cherries is not well known, although it seems to be related to cultivars.

The main objective of this work was to study the physical, chemical and nutritional quality of 'Sweetheart' cherry stored under different conditions during a period of 27 days.

\section{MATERIAL AND METHODS}

The sweet cherry 'Sweetheart' fruits were harvested at commercial maturation, from an orchard in S. Julião region (Alentejo, Portugal). The designation of "ripe" corresponds to fruit harvested at the usual stage of maturity for this cultivar at the region. Considering that fruit color is a consistent and reliable maturity índex, fruit were selected with light mahogany external colour and TSS near $20^{\circ}$ Brix.

CC and MA samples were carefully accommodated in $1-\mathrm{kg}$ plastic boxes, transported at $20^{\circ} \mathrm{C}$ to the Post-harvest and Technology Laboratory at the University of Évora, and selected considering visual defects and size. CA samples were immediately transported at $20^{\circ} \mathrm{C}$ to INTAEX. Both INTAEX and University of Évora are located at $100 \mathrm{~km}$ from the orchard. Samples for MA treatment were packed in perforated bags of Pplus ${ }^{\circledR}$ (Sidlaw Packaging, Bristol, UK). Groups of three samples of 30 fruit each were kept in different storage conditions: cold conditions $\mathrm{CC}\left(1^{\circ} \mathrm{C}, 95 \% \mathrm{RH}\right)$; modified atmosphere MA $\left(1^{\circ} \mathrm{C}, 95 \% \mathrm{RH}\right.$ with Pplus bags); controlled atmosphere $\mathrm{CA}\left(1^{\circ} \mathrm{C}, 95 \%\right.$ $\mathrm{RH}, 10 \% \mathrm{CO}_{2}$ and $8 \% \mathrm{O}_{2}$ ).

The experimental design was a factorial: storage method (CC, MA, and $\mathrm{CA})$ and storage period $(0,6,13,20$ and 27 days). Fruits from day 0 , considered without storage, were kept at $20^{\circ} \mathrm{C}$ and analysed after temperature stabilization. Every sampling day, 90 fruits of each treatment, were randomly picked up and submitted to several analyses, all groups were analysed after fruit temperature stabilised at $20^{\circ} \mathrm{C}$.

\section{Physical and Chemical Analysis}

Cherries weight was determined to the nearest $0.01 \mathrm{~g}$ (Mettler Toledo PB 1502) and weight loss between day 0 and each sampling day was calculated. External colour (colour space coordinates $\mathrm{L}^{*} \mathrm{a}^{*} \mathrm{~b}^{*}$ ) was measured in the equatorial zone using a colorimeter (Minolta CR-300). Total soluble solids (TSS) was measured twice on juice from each group of 30 fruits, using a digital refractometer (Atago model PR-101), and results were expressed in ${ }^{\circ}$ Brix. Titratable acidity (TA) was measured on juice from each group of 30 cherries, using a Crison Compact Titrator with $0.1 \mathrm{~N} \mathrm{NaOH}$ (ISO 750 1981), and results were expressed as percent malic acid.

For phenolic compounds analysis, extracts were obtained from $1 \mathrm{~g}$ of freeze dried fruits with $10 \mathrm{ml}$ of acidified methanol $(0.2 \% \mathrm{HCl})$. After 16 hours at $-22^{\circ} \mathrm{C}$, samples were centrifuged at $10000 \mathrm{rpm}$ for $15 \mathrm{~min}$ and filtered. Total polyphenols content was assessed using the Folin-Ciocalteu phenol (Singleton and Rossi, 1965) and expressed as Gallic Acid Equivalents (GAE) in $\mathrm{mg}$ per $100 \mathrm{~g}$ fresh weight (FW). The total anthocyanins was determined according to the modified method of Ribereau-Gayon and Stonestreet (1965) and expressed as Malvidin Equivalents in mg per $100 \mathrm{~g}$ of FW. The determination of antioxidant activity of the extract was evaluated using DPPH radical scavenging assay (Brand Williams et al., 1995). The percentage inhibition of DPPH was calculated according to the formula:

$$
\% \text { Inhibition }=\left[\frac{A b-A a}{A b}\right] \times 100
$$


where $A b$ is the absorption of blank sample $(\mathrm{t}=0)$ and $A a$ is the absorption of extract sample at the end of reaction $(\mathrm{t}=30 \mathrm{~min})$.

\section{Data Analysis}

Analysis of variance was applied to physicochemical and nutritional values considering two variables, storage period and storage method. Mean comparisons were performed using Bonferroni test for $\mathrm{p}<0.05$. A Principal Component Analysis (PCA) was also performed. For the statistical analysis Statistica 6.0 program was used.

\section{RESULTS AND DISCUSSION}

\section{Weight Loss}

Weight loss in the MA treatment was consistently the lowest, and unexpectedly the CA treatment resulted in variable weight, in the 13-d sample there was water condensation on the surface of fruits. This should be kept in mind since it can affect results. Weight loss of fruits stored under CA conditions showed significant differences from fruits stored under other storage treatments after all storage periods (Table 1). Only at the last sampling day a significant difference between MA fruits and refrigerated fruits (CC) was revealed.

\section{Colour Coordinates $L * a * b *$}

Cherry brightness ( $\mathrm{L}^{*}$ value) was not influenced by storage period or storage methods, although after 27 days a significant difference was observed between cherries from CA and MA (Table 2).

The $\mathrm{a}^{*}$ and $\mathrm{b}^{*}$ colour values decreased for cherries stored under CC and MA conditions, although no significant differences were found. Fruits from CA showed an increase in both values from day 13 and were significantly different from day 20.

\section{Phenolic Compounds and Antioxidant Activity}

Total anthocyanins values remained stable during all storage periods in all treatments. However total anthocyanins concentrations of fruits stored under CA were lower than concentrations of fruits stored under MA and CC conditions. A slight decrease in anthocyanins of fruits from CA can be noticed. None of the differences were significant $(\mathrm{p}>0.05)$.

Total antioxidant activity values also revealed no significant differences $(p>0.05)$ considering storage time or storage method, and that should be pointed out as an advantage for nutritional purposes. Fruits stored under CA conditions tended to have the lowest antioxidant activity, reaching very low values after 20 days of storage.

Total phenolics values were stable until 13 days of storage. At that time there were significant differences $(\mathrm{p}<0.05)$ between cherries stored under CA conditions and fruits from the other storage treatments. Total polyphenols values obtained in fruits of CA method were always the lowest. These results allow us to conclude that this parameter is almost stable during storage with worst values for the CA method mainly after 13 days of storage.

\section{TSS and Titratable Acidity}

As expected, acidity decreased during storage period for all treatments. However, in each storage period fruits from CA conditions exhibited the lowest values, but only after a storage period of 20 days were significantly different from MA and CC fruits. The storage treatment did not influence the TSS values until 13 days. After that fruits from CA treatment showed the lowest values in each storage period.

\section{Principal Component Analysis (PCA)}

A PCA was performed to find correlation among the variables (Fig. 1). These results showed that the measurements of phenolic compounds in general (total antho- 
cyanins (TA), total phenolics (TP) and antioxidant activity) are inversely correlated with colour coordinates $\left(\mathrm{L}^{*}, \mathrm{a}^{*}, \mathrm{~b}^{*}\right)$, and TSS and titratable acidity are very close to those measured phenolics compounds.

\section{CONCLUSIONS}

'Sweetheart' cherry nutritional quality was monitored by evaluating phenolic compounds which were relatively stable and similar during storage in $\mathrm{CC}$ and $\mathrm{MA}$ conditions. Cherries stored under $\mathrm{CA}$ conditions $\left(1{ }^{\circ} \mathrm{C}, 95 \% \mathrm{RH}, 10 \% \mathrm{CO}_{2}\right.$ and $\left.8 \% \mathrm{O}_{2}\right)$ presented lowest concentrations of phenolic compounds. Phenolic compounds, total anthocyanins and antioxidant activity were inversely correlated with values of colour coordinates. Considering all the evaluations done during this work, and the goal of distinguishing among these storage methods, is unquestionable that fruits stored in controlled atmosphere conditions had significantly different quality.

\section{ACKNOWLEDGEMENTS}

To RITECA/INTERREG for support of this research work.

\section{Literature Cited}

Agulheiro-Santos, V., Palma, D., González, G., Machado, G., Rato, A.E., Lozano, M. and Gónzález, D. 2009. Quality evaluation of cherry 'Sweetheart' under different storage conditions. $6^{\text {th }}$ International Cherry Symposium. Viñas del Mar, Chile.

Andre, P., Blanc, R., Buret, M., Chambroy, Y., Flanzy, C., Pelisd, C. and Dauple, P. 1982. Storage trials of red cherries for fresh consumption. Revue Hort. 226:35.

Bernalte, M.J., Sabio, E., Hernandéz, M.T. and Gervasini, C. 2003. Influence of storage delay on quality of 'Van'- sweet cherry. Postharvest Biol. Technol. 28:303-312.

Brand-Williams, W., Cuvelier, M.E. and Berset, C. 1995. Use of free radical method to evaluate antioxidant activity. Lebensm. Wiss. Technol. Food Sci. 28:25-30.

Chapon, J.F. and Bony, P. 1990. Cherries. The importance of modified atmospheres in maintaining quality. Infos (Paris) 62:11-14.

Chen, P.M., Mellenthin, W.M., Kelly, S.B. and Facteau, T.J. 1981. Effects of low oxygen and temperature on quality retention of 'Bing' cherries during prolonged storage. J. Amer. Soc. Hort. Sci. 106:533.

Conte, A., Scrocco, C., Lecce, L., Mastromatteo, M. and Del Nobile, M.A. 2009. Ready to eat sweet cherries: study on different packaging systems. Innov. Food Sci. Emerg. Technol. 10:564-571.

Crisosto, C.H., Crisosto, G.M. and Metheney, P. 2003. Consumer acceptance of 'Brooks' and 'Bing' cherries is mainly dependent on fruit SSC and visual skin color. Postharvest Biol. Technol. 24:147-154.

Esti, M., Cinquanta, L., Sinesio, F., Moneta, E. and Di Matteo, M. 2002. Physicochemical and sensory fruit characteristics of two sweet cherry cultivars after cool storage. Food Chem. 76:399-405.

Gonçalves, B., Silva, A.P., Moutinho-Pereira, J., Bacelar, E., Rosa, E. and Meyer, A.S. 2007. Effect of ripeness and postharvest storage on the evolution of colour and anthocyanins in cherries (Prunus avium L.). Food Chem. 103:976-984.

Looney, N.E., Webster, A.D. and Kupferman, E.M. 1996. Cherries: crop physiology, production and uses. CAB International, Wallingford, Oxon, UK.

Meheriuk, M., Girard, B., Moyls, L., Beveridge, H.J.T., McKenzie, D.-L., Harrison, J., Weintraub, S. and Hocking, R. 1995. Modified atmosphere packaging of 'Lapins' sweet cherry. Food Res. Intl. 28:239-244.

Navarro, P., Martinez-jávega, J.M. and Del Río, M.A. 1993. Influencia de la prerefrigeración y embalaje en el armacenamiento frigorífico de cerezas cv. Starking. Actas II Congreso Ibérico de Ciencias Hortícolas. Zaragoza.

Patterson, M.E. 1982. CA storage of cherries. p.149-154. In: D.G. Richardson and M. Meheriuk (eds.), Proc. $3^{\text {rd }}$ Natl. CA Conf., Corvallis, Oregon.

Petracek, P.D., Joles, D.W., Shirazi, A. and Cameron, A.C. 2002. Modified atmosphere 
packaging of sweet cherry (Prunus avium L. Ev. 'Sams') fruit: metabolic responses to oxygen carbon dioxide, and temperature. Postharvest Biol. Technol. 24:259-270.

Porritt, S.W. and Mason, J.L. 1965. Controlled atmosphere storage of sweet cherries. Proc. Amer. Soc. Hort. Sci. 87:128.

Ribereau-Gayon, P. and Stonestreet, E. 1965. Le dosage des anthocyanes dans les vins rouges. Bull. Soc. Chim. 9:2649-2652.

Sampaio, A., Agulheiro-Santos, A.C. and Oliveira, C.M. 2006. Efeito de diferentes estados de maturação à colheita na capacidade de conservação de cereja 'Sunburst'. VIII Simposio Nacional y Ibérico de Maduración y Post-Recolección. Orihuela 27-30 Septiembre 2006.

Singleton, V.L. and Rossi, J.A. 1965. Colourometry of total phenolics with phosphomolybdic-phospholungistic acid reagents. Am. J. Enol. Vitic. 16:144-158.

Vursavus, K., Kelebek, H. and Selli, S. 2006. A study on some chemical and physicmechanic properties of three sweet cherry varieties (Prunus avium L.) in Turkey. J. Food Eng. 74:568-575.

\section{Tables}

Table 1. Weight loss, total polyphenolics, total anthocyanins, and antioxidant activity of 'Sweetheart" sweet cherry stored at $1^{\circ} \mathrm{C}$ in cold conditions (CC) in air, modified atmosphere (MA) and controlled atmosphere (CA) for a period of 27 days. Data are means \pm standard deviations. Different letters for a given parameter and date indicate significantly different values at $\mathrm{p}<0.05$.

\begin{tabular}{lccccc}
\hline $\begin{array}{l}\text { Date } \\
\text { (days) }\end{array}$ & $\begin{array}{c}\text { Storage } \\
\text { method }\end{array}$ & $\begin{array}{c}\text { Weight } \\
\text { loss } \\
(\%)\end{array}$ & $\begin{array}{c}\text { Total } \\
\text { polyphenols } \\
(\mathrm{mgGAE} / \\
100 \mathrm{~g} \mathrm{FW})\end{array}$ & $\begin{array}{c}\text { Total } \\
\text { anthocyanins } \\
(\mathrm{mg} \mathrm{ME} /\end{array}$ & $\begin{array}{c}\text { Antioxidant } \\
\text { activity } \\
(\% \mathrm{~g} \mathrm{FW})\end{array}$ \\
\hline 0 & - & -- & $97.1 \pm 9.40$ & $34.2 \pm 9.07$ & $11.3 \pm 6.30$ \\
\hline 6 & $\mathrm{CC}$ & $-1.52 \mathrm{a} \pm 0.97$ & $99.1 \mathrm{a} \pm 14.88$ & $40.2 \mathrm{a} \pm 9.52$ & $13.42 \mathrm{a} \pm 5.70$ \\
6 & MA & $-1.3 \mathrm{a} \pm 0.83$ & $98.1 \mathrm{a} \pm 4.29$ & $41.7 \mathrm{a} \pm 10.59$ & $14.5 \mathrm{a} \pm 3.69$ \\
6 & $\mathrm{CA}$ & $3.0 \mathrm{~b} \pm 0.85$ & $93.7 \mathrm{a} \pm 13.82$ & $31.3 \mathrm{a} \pm 12.54$ & $9.4 \mathrm{a} \pm 4.75$ \\
\hline 13 & $\mathrm{CC}$ & $-1.8 \mathrm{a} \pm 0.13$ & $98.7 \mathrm{a} \pm 2.48$ & $38.9 \mathrm{a} \pm 2.38$ & $9.7 \mathrm{a} \pm 2.22$ \\
13 & MA & $-1.3 \mathrm{a} \pm 0.86$ & $92.0 \mathrm{a} \pm 8.13$ & $29.9 \mathrm{a} \pm 7.32$ & $9.1 \mathrm{a} \pm 5.67$ \\
13 & $\mathrm{CA}$ & $0.1 \mathrm{~b} \pm 0.05$ & $80.2 \mathrm{a} \pm 9.86$ & $25.6 \mathrm{a} \pm 7.18$ & $7.3 \mathrm{a} \pm 12.22$ \\
\hline 20 & CC & $-2.2 \mathrm{a} \pm 0.20$ & $92.7 \mathrm{~b} \pm 10.93$ & $30.6 \mathrm{a} \pm 4.12$ & $11.7 \mathrm{a} \pm 4.67$ \\
20 & MA & $-1.5 \mathrm{a} \pm 1.12$ & $97.0 \mathrm{~b} \pm 7.21$ & $36.6 \mathrm{a} \pm 6.95$ & $10.0 \mathrm{a} \pm 5.43$ \\
20 & $\mathrm{CA}$ & $2.3 \mathrm{~b} \pm 0.66$ & $69.2 \mathrm{a} \pm 14.13$ & $19.4 \mathrm{a} \pm 10.99$ & $4.3 \mathrm{a} \pm 8.77$ \\
\hline 27 & CC & $-2.9 \pm 0.04$ & $100.2 \mathrm{~b} \pm 5.77$ & $39.7 \mathrm{a} \pm 15.10$ & $16.2 \mathrm{a} \pm 6.51$ \\
27 & MA & $-1.3 \pm 0.06$ & $98.4 \mathrm{~b} \pm 8.32$ & $42.7 \mathrm{a} \pm 13.29$ & $17.8 \mathrm{a} \pm 6.71$ \\
27 & $\mathrm{CA}$ & $3.7 \pm 0.63$ & $74.1 \mathrm{a} \pm 8.35$ & $23.3 \mathrm{a} \pm 6.86$ & $7.9 \mathrm{a} \pm 6.31$ \\
\hline
\end{tabular}


Table 2. Colour parameters L* $\mathrm{a}^{*} \mathrm{~b}$ *, TSS and TA of "Sweetheart" sweet cherry stored at $1^{\circ} \mathrm{C}$ in cold conditions (CC) in air, modified atmosphere (MA) and controlled atmosphere (CA) for a period of 27 days. Data are means \pm standard deviations. Different letters for a given parameter and date indicate significantly different values at $\mathrm{p}<0.05$.

\begin{tabular}{ccccccc}
\hline $\begin{array}{c}\text { Date } \\
\text { (days) }\end{array}$ & $\begin{array}{c}\text { Storage } \\
\text { method }\end{array}$ & \multicolumn{1}{c}{$\mathrm{L}^{*}$} & \multicolumn{1}{c}{$\mathrm{a}^{*}$} & \multicolumn{1}{c}{$\mathrm{b}^{*}$} & $\begin{array}{c}\text { TSS } \\
\left({ }^{\circ} \text { Brix }\right)\end{array}$ & $\begin{array}{c}\text { TA } \\
(\% \text { malic acid })\end{array}$ \\
\hline 0 & - & $34.1 \pm 0.16$ & $25.3 \pm 0.69$ & $6.4 \pm 0.43$ & $20.6 \pm 0.61$ & $0.87 \pm 0.04$ \\
\hline 6 & CC & $32.3 \mathrm{a} \pm 3.05$ & $23.4 \mathrm{a} \pm 2.61$ & $5.8 \mathrm{a} \mathrm{b} \pm 0.72$ & $20.4 \mathrm{a} \pm 0.35$ & $0.81 \mathrm{a} \pm 0.06$ \\
6 & MA & $33.3 \mathrm{a} \pm 0.34$ & $24.5 \mathrm{a} \pm 0.51$ & $6.1 \mathrm{a} \pm 0.44$ & $20.6 \mathrm{a} \pm 0.32$ & $0.81 \mathrm{a} \pm 0.06$ \\
6 & CA & $33.7 \mathrm{a} \pm 0.25$ & $25.3 \mathrm{a} \pm 0.28$ & $6.3 \mathrm{~b} \pm 0.12$ & $19.8 \mathrm{a} \pm 0.39$ & $0.79 \mathrm{a} \pm 0.01$ \\
\hline 13 & CC & $32.9 \mathrm{a} \pm 0.57$ & $23.3 \mathrm{a} \pm 0.50$ & $5.7 \mathrm{ab} \pm 0.26$ & $20.6 \mathrm{~b} \pm 0.83$ & $0.78 \mathrm{a} \pm 0.05$ \\
13 & MA & $32.7 \mathrm{a} \pm 0.22$ & $22.0 \mathrm{a} \pm 1.22$ & $5.2 \mathrm{a} \pm 0.61$ & $20.5 \mathrm{~b} \pm 0.48$ & $0.81 \mathrm{a} \pm 0.02$ \\
13 & CA & $33.5 \mathrm{a} \pm 0.50$ & $24.6 \mathrm{a} \pm 0.91$ & $6.3 \mathrm{~b} \pm 0.35$ & $19.0 \mathrm{a} \pm 0.45$ & $0.74 \mathrm{a} \pm 0.04$ \\
\hline 20 & CC & $33.1 \mathrm{a} \pm 0.29$ & $22.3 \mathrm{ab} \pm 0.50$ & $4.9 \mathrm{a} \pm 0.11$ & $20.4 \mathrm{~b} \pm 0.66$ & $0.77 \mathrm{~b} \pm 0.03$ \\
20 & MA & $32.8 \mathrm{a} \pm 0.17$ & $21.6 \mathrm{a} \pm 0.96$ & $4.8 \mathrm{a} \pm 0.43$ & $20.2 \mathrm{~b} \pm 0.23$ & $0.73 \mathrm{ab} \pm 0.03$ \\
20 & CA & $33.4 \mathrm{a} \pm 0.84$ & $25.5 \mathrm{~b} \pm 1.41$ & $7.1 \mathrm{~b} \pm 0.56$ & $18.6 \mathrm{a} \pm 0.46$ & $0.67 \mathrm{a} \pm 0.03$ \\
\hline 27 & CC & $32.6 \mathrm{a} \mathrm{b} \pm 0.80$ & $21.8 \mathrm{a} \pm 1.21$ & $4.8 \mathrm{a} \pm 0.45$ & $20.6 \mathrm{~b} \pm 0.89$ & $0.72 \mathrm{ab} \pm 0.05$ \\
27 & MA & $32.2 \mathrm{a} \pm 1.79$ & $21.8 \mathrm{a} \pm 0.68$ & $4.8 \mathrm{a} \pm 0.17$ & $19.8 \mathrm{~b} \pm 0.44$ & $0.73 \mathrm{~b} \pm 0.02$ \\
27 & CA & $34.6 \mathrm{~b} \pm 0.39$ & $26.5 \mathrm{~b} \pm 0.73$ & $6.8 \mathrm{~b} \pm 0.31$ & $18.0 \mathrm{a} \pm 0.77$ & $0.7 \mathrm{a} \pm 0.01$ \\
\hline
\end{tabular}

\section{Figures}

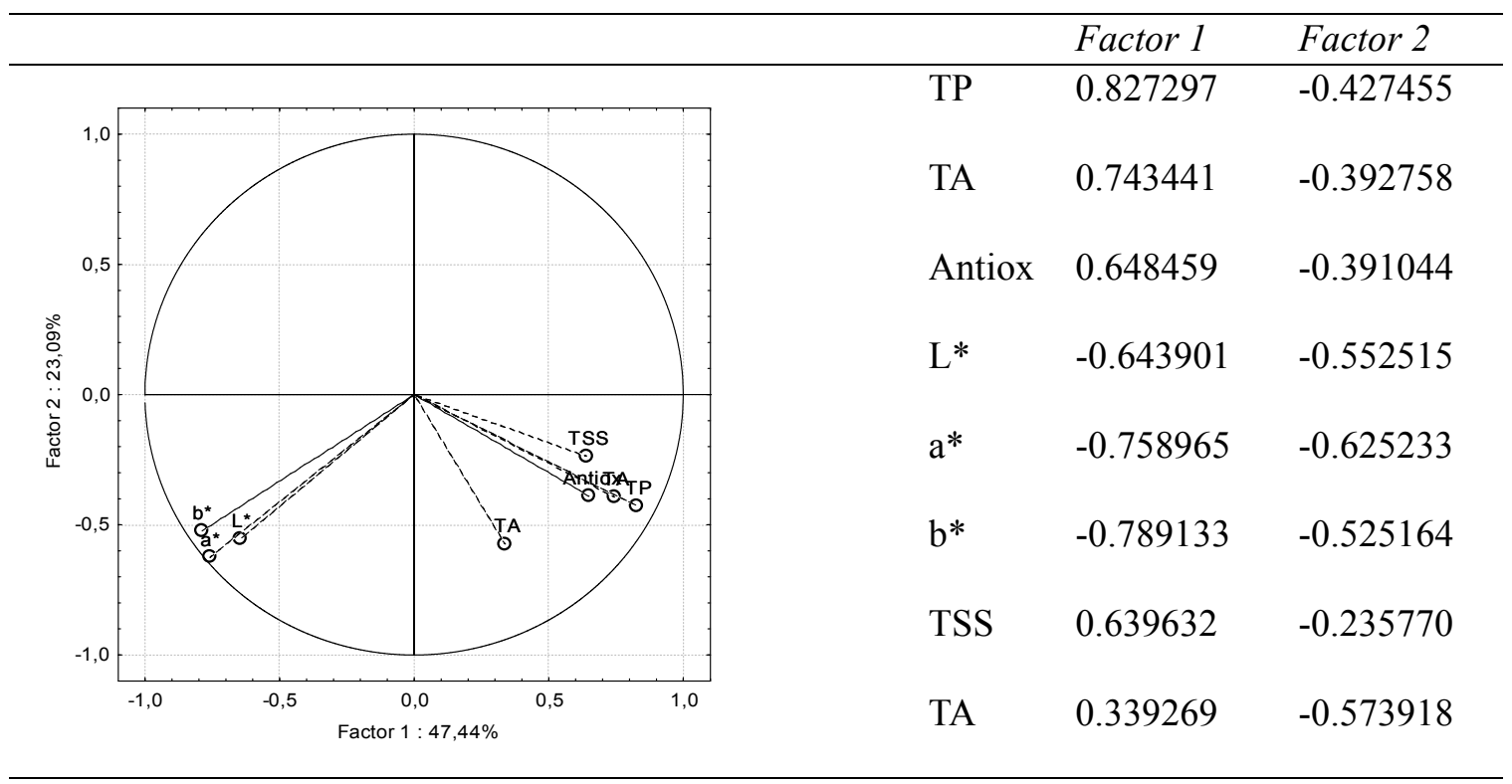

Fig. 1. Projection of the variables on the factor-plan $(1 \times 2)$ and factor coordinates of the variables used in PCA (TP, TA, Antiox, L*, a*, b*, TSS, TA). 